\title{
Desensitization to Allopurinol in Localized and Systemic Hypersensitivity Reactions
}

Gomes R, Ribeiro F, Faria E, Loureiro C* and Segorbe-Luís A

Immunoallergology Department, Coimbra University Hospital, Portugal

\begin{abstract}
Introduction: Allopurinol is, by far, the most frequently prescribed drug for the treatment of hyperuricemia, and the lack of alternatives makes, in case of a reaction, a desensitization procedure to be considered. With this survey, we aimed to do a characterization of patients with hypersensitivity (HS) reactions to allopurinol, who endured desensitization procedures.
\end{abstract}

Material and methods: Retrospectively, we analyzed the medical files of a group of patients that fit into our objective and were observed in our Department of Immunoallergology of Coimbra University Hospital, between 2007/2012. Demographic data, pathology underlying all prescriptions and concomitant diseases/regular medication, the desensitization protocol and all adverse reactions were taken into consideration.

Results: Six out of seven patients were male, aged from 37 to 79 (mean age of $64 \pm 14$ years) when undergoing the procedure. As far as the kind of reaction was concerned, three of the patients presented a fixed erythema, two urticaria with/without angiodema, one anaphylaxis and another one maculopapular rash at the time of desensitization. Five of them had gouty joint pathology, one hyperuricemia with chronic renal failure and another had both. Six among all of them presented associated cardiovascular pathology and were polymedicated.

The desensitization protocol used was adapted from Umpiérrez, with an initial dose of $10 \mu \mathrm{g}$ up to $300 \mathrm{mg} / \mathrm{day}$, adjusted in case of adverse reaction. There were no complications in three patients and the remaining had mild/ moderate skin reactions. In four patients with HS reaction during desensitization, only three needed to decrease the dose. The maintenance dose was achieved by extending the length of desensitization, between sixteen to twentytwo days.

Conclusion: In this series, the majority of patients had HS reactions during desensitization protocol and dose adjustment was necessary. However, we managed to achieve a maintenance dose in all of them.

Keywords: Desensitization; Allopurinol; Hyperuricemia; Localized and systemic hypersensitivity

\section{Introduction}

Allopurinol (4-hidroxipirazolol piramidine) is the first line therapy employed to treat hyperuricemia. It is an inhibitor of the enzymexanthine oxidase which is responsible for the successive oxidation of hypoxanthine andxanthine, resulting in the production of uric acid [1]. In addition to blocking uric acid production it may also inhibit purine synthesis [2]. Although it is a well-tolerated drug, there are descriptions of HSreactions to treatment with variable degree of incidence and severity. The most frequent reactions are morbilliform rash/pruritic erythematous maculopapular rash (2\%) [3,4], and, less frequently, patients may experience life-threateningdermatologica lconditionslikeDRESS (Drug Rash with Eosinophilia and Systemic Symptoms) (0.4\%) [5], SJS (Stevens-Johnson syndrome) or TEN (Toxic Epidermal Necrolysis) [6].

Recent studies have demonstrated the association between human leukocyte antigen (HLA) $B^{\star 5}$ 58:01 allele and allopurinol-induced severe cutaneous adverse reactions, this aspect might explain ethnic differences in incidence [7]. In allopurinol HS, there are data suggesting that the starting dose may be relevant for the development of HS [8].

In some countries, the uricosuric drugs (probenecid, benzbromarone and sulfinpyrazone), which increase the excretion of uric acidin theurine, are utilized in the chronic treatment of gout but they are not available in the Portuguese market [9]. Thereby we have very limited alternatives in treating patients with gout and allopurinol hypersensitivity, and a desensitization procedure must be considered.
The first description of desensitization to allopurinol was reported by Meyrieri [10]. In the next decades, several case reports with oral and intravenous protocols were published [10-17]. We emphasize the cases series from Fam et al. [18] and Lopes da Silva et al. [9] which included a higher number of patients, 32 and 9 patients, respectively.

The mechanisms involved in the desensitization to allopurinol are not well understood and several pathways were proposed. Teraki and Shiohara [11] reported a patient with fixed erythema submitted to allopurinol desensitization; the authors showed that intraepidermal $\mathrm{CD} 8+\mathrm{T}$ cells in the attained skin are the main cells present before the desensitization, whereas a significant number of CD25+CD4+ T cells were present after the procedure, supporting that, probably these cells may be involved in the induction of desensitization. The HS reactions to allopurinol may be immunologically mediated (via $\mathrm{T}$ cell response to oxipurinol or alopurinol [19-21] or secondary to immune complexes and so considered true HS allergic reactions, or be associated with toxic effects resulting from accumulation of oxipurinol and alopurinol [19-

*Corresponding author: Loureiro Carlos, Immunoallergology Department Coimbra University Hospital, Portugal, E-mail: acnl@sapo.pt

Received May 15, 2013; Accepted June 14, 2013; Published June 20, 2013

Citation: Gomes R, Ribeiro F, Faria E, Loureiro C, Segorbe-Luís A (2013) Desensitization to Allopurinol in Localized and Systemic Hypersensitivity Reactions. J Allergy Ther 4: 138. doi:10.4172/2155-6121.1000138

Copyright: @ 2013 Gomes R, et al. This is an open-access article distributed unde the terms of the Creative Commons Attribution License, which permits unrestricted use, distribution, and reproduction in any medium, provided the original author and source are credited. 
26]. The aim of this study was to perform a retrospective analysis of patients with allopurinol HS reactions who underwent a desensitization procedure in our Immunoallergology Department from 2007 to 2012.

\section{Material and Methods}

\section{Patient population}

We analyzed, retrospectively, the medical files of patients with allopurinol HS reactions who underwent desensitization, observed in our department in a six year period (January 2007 to December 2012). The study included seven patients, with severe gouty arthritis or other hyperuricemic states requiring urate-lowering therapy with allopurinol. These patients had a well-documented recurrent history of HS reaction to allopurinol recorded by the examining physician, which resolved after discontinuation of the drug, and who, subsequently, underwent oral desensitization to allopurinol.

Patients with severe reactions to allopurinol, like DRESS, TEN or SJS, were not submitted to desensitization. Based on data of other studies $[12,18]$ patients did not undergo desensitization if their hemoglobin value was $<9.0 \mathrm{~g} / \mathrm{dL}$, total leukocyte count $<4000 \mathrm{cells} / \mathrm{mm}^{3}$, platelet count was $<100000$ cells $/ \mathrm{mm}^{3}$, liver function tests 2 -fold elevated.

The demographic data, pathology that motivated prescription of allopurinol and concomitant diseases/medications were evaluated. Demographic data included age at the time of the desensitization, clinical manifestations of delayed HS reaction, indication for allopurinol therapy (primary diagnostic), concomitant diseases, chronic medication and complementary diagnostic exams performed (before and after desensitization process).

\section{Desensitization procedure}

Patient's informed consent was obtained. The desensitization protocol used was adapted from Umpiérrez et al. [27]. It is a 16 days protocol with increasing allopurinol dosage beginning with $10 \mu \mathrm{g}$ up to a dose of $300 \mathrm{mg}$ (Table 1). This protocol was adjusted if an adverse reaction occurred, repeating the last tolerated dose after treating the reaction, consequently increasing the desensitization timing procedure.

A suspension of allopurinol was prepared by our hospital's pharmacy with a $200 \mu \mathrm{g} / \mathrm{ml}$ allopurinol concentration. Unit doses containing 25 $\mathrm{mg}, 50 \mathrm{mg}$ and $100 \mathrm{mg}$ were prepared. Successful desensitization was defined as the ability to tolerate allopurinol at a dosage $\geq 100 \mathrm{mg} /$ day,

\begin{tabular}{|c|c|c|c|}
\hline Day & \multicolumn{3}{|c|}{ Dose } \\
\hline $\mathbf{1}^{\text {st }}$ & $10 \mu \mathrm{g}$ & $20 \mu \mathrm{g}$ & $30 \mu \mathrm{g}$ \\
\hline $\mathbf{2}^{\text {nd }}$ & $40 \mu \mathrm{g}$ & $50 \mu \mathrm{g}$ & $60 \mu \mathrm{g}$ \\
\hline $\mathbf{3}^{\text {rd }}$ & $70 \mu \mathrm{g}$ & $80 \mu \mathrm{g}$ & $90 \mu \mathrm{g}$ \\
\hline $\mathbf{4}^{\text {th }}$ & $100 \mu \mathrm{g}$ & $200 \mu \mathrm{g}$ & $400 \mu \mathrm{g}$ \\
\hline $\mathbf{5}^{\text {th }}$ & $600 \mu \mathrm{g}$ & $800 \mu \mathrm{g}$ & $1 \mathrm{mg}$ \\
\hline $\mathbf{6}^{\text {th }}$ & $2 \mathrm{mg}$ & $4 \mathrm{mg}$ & $8 \mathrm{mg}$ \\
\hline $\mathbf{7}^{\text {th }}$ & $16 \mathrm{mg}$ & $25 \mathrm{mg}$ & $35 \mathrm{mg}$ \\
\hline $\mathbf{8}^{\text {th }}$ & $50 \mathrm{mg}$ & - & - \\
\hline $\mathbf{9}^{\text {th }}$ & $75 \mathrm{mg}$ & - & - \\
\hline $\mathbf{1 0}^{\text {th }}$ & $100 \mathrm{mg}$ & - & - \\
\hline $\mathbf{1 1}^{\text {th }}$ & $125 \mathrm{mg}$ & - & - \\
\hline $\mathbf{1 2}^{\text {th }}$ & $150 \mathrm{mg}$ & - & - \\
\hline $\mathbf{1 3}^{\text {th }}$ & $175 \mathrm{mg}$ & - & - \\
\hline $\mathbf{1 4}^{\text {th }}$ & $200 \mathrm{mg}$ & - & - \\
\hline $\mathbf{1 5}^{\text {th }}$ & $250 \mathrm{mg}$ & - & - \\
\hline $\mathbf{1 6}^{\text {th }}$ & $300 \mathrm{mg}$ & - & - \\
\hline
\end{tabular}

Table 1: Desensitization protocol adapted from Umpiérrez et al. [27]; $1 \mathrm{~h}$ interva between doses.

\begin{tabular}{|c|c|c|}
\hline Feature & \multicolumn{2}{|l|}{ Frequency (Total=7) } \\
\hline Age, mean (range) years & \multicolumn{2}{|l|}{$64(37-79)$} \\
\hline Sex (men/women) & \multicolumn{2}{|l|}{$6 / 1$} \\
\hline \multirow[t]{3}{*}{ Indication for desensitization } & $\begin{array}{l}\text { Tophi and chronic tophaceous } \\
\text { gouty arthritis }\end{array}$ & 6 \\
\hline & Chronic renal failure & 2 \\
\hline & Uric acid nephropathy & 1 \\
\hline Serum urate mean (range) $\mathrm{mg} / \mathrm{dL}$ & \multicolumn{2}{|l|}{$10.2(7.2-14.0)$} \\
\hline Serum creatinine (range) mg/dL & \multicolumn{2}{|l|}{$0.7-2.48$} \\
\hline
\end{tabular}

Table 2: Demografic characteristics of the 7 patients who underwent allopurinol.

in agreement with the patient's assistant physician, who determined the necessary dose. The time taken to reach the target dosage and the occurrence of adverse events was documented and analyzed.

\section{Results}

Seven patients met the criteria to be included in the study. Clinical characteristics of the population are outlined in table 2.

Six out of seven patients were male, with ages between 37 and 79 years (mean age of $64 \pm 14$ years) at the time of desensitization. All patients initiated complaints more than 1 hour after drug intake. The type of reaction was fixed erythema in three patients, urticaria with or without angioedema in two, anaphylaxis in one and pruritic maculopapular rash in one patient. Six patients had gouty joint pathology with hyperuricemic state; one had hyperuricemia with chronic renal failure and one had both; all patients with gouty joint pathology experienced recurrent gouty attacks. Only one patient with gout had a history of renal calculi. Six patients had associated cardiovascular pathology (hypertension in six, coronary disease and arrhythmia in one, dyslipidemia in two, cardiac valvular disease in one) and two had renal disease (one chronic renal failure and one uric nephropathy). All patients were polymedicated and three of these were medicated with beta-blockers which were discontinued after discussion with the assistant cardiologists.

There were no complications in the progression of the protocol in three patients (43\%) and the remaining had mild to moderate skin reactions: two patients had reappearance of fixed erythema, one patient had urticarial lesions on the upper limbs and one patient had maculopapular rash. One out of two patients who experienced fixed erythema was treated with oral antihistamine and topical corticosteroid and repeated dose during two days, until tolerance was achieved (patient 1); he then continued without further complications until reach a dose of $300 \mathrm{mg}$. Patient 2, also with fixed erythema, required neither treatment nor dose adjustment. Patient 5 , that experienced urticaria, required dose adjustment for 4 times, was treated with intramuscular antihistamine and was also premedicated daily with cetrizine to achieve $300 \mathrm{mg} / \mathrm{day}$, which was afterword discontinued without reaction. Finally, patient 6 , who had maculopapular rash in the upper body was treated with parenteral antihistamine and corticosteroid and needed one dose adjustment, reaching a dose of $150 \mathrm{mg}$ /day (Table 3). These cutaneous reactions occurred at allopurinol dosages $\leq 75 \mathrm{mg} /$ day in all patients. One patient reacted at a much lower dose of only $240 \mu \mathrm{g} /$ day. With the adjustments the time of desensitization procedure varied between 16 and 22 days.

No patient experienced any serious hypersensitivity reactions, significant abnormal laboratory findings, or required emergency department care.

The overall success rate of desensitization was $100 \%$, since the maintenance dose therapy (at least $100 \mathrm{mg}$ /day) was achieved in all 
Citation: Gomes R, Ribeiro F, Faria E, Loureiro C, Segorbe-Luís A (2013) Desensitization to Allopurinol in Localized and Systemic Hypersensitivity Reactions. J Allergy Ther 4: 138. doi:10.4172/2155-6121.1000138

Page 3 of 4

\begin{tabular}{|c|c|c|c|c|c|c|c|c|}
\hline Patient & Age & Sex & Primary diagnostic & $\begin{array}{l}\text { Concomitant } \\
\text { diseases }\end{array}$ & Chronic medication & HS reaction & $\begin{array}{l}\text { Final dose } \\
\quad(\mathrm{mg})\end{array}$ & Complications \\
\hline 1 & 73 & M & Gouty joint pathology & $\mathrm{HBP}$ & $\begin{array}{l}\text { Losartan } \\
\text { Colchicine }\end{array}$ & Fixed erythema & 300 & $\begin{array}{c}2^{\text {nd }} \text { day: Fixed erythema } \\
\text { (oral antihistamine and topical } \\
\text { corticosteroid) }\end{array}$ \\
\hline 2 & 76 & M & $\begin{array}{l}\text { Hyperuricemia with } \\
\text { chronic renal failure }\end{array}$ & HBP & $\begin{array}{c}\text { Colchicine } \\
\text { Trimetazidine } \\
\text { Candesartan/HCTZ } \\
\text { CarvedilolLercanidipine } \\
\text { Fibrate } \\
\text { Alprazolam } \\
\text { Clopidogrel }\end{array}$ & Fixed erythema & 100 & $\begin{array}{l}3^{\text {th }} \text { and } 6^{\text {th }} \text { days: } \\
\text { Fixed erythema }\end{array}$ \\
\hline 3 & 57 & M & Gouty joint pathology & $\begin{array}{c}\text { HBP } \\
\text { Coronary disease } \\
\text { FA Dyslipidemia }\end{array}$ & $\begin{array}{l}\text { Colchicine } \\
\text { Valsartan } \\
\text { Bisoprolol } \\
\text { Clopidogrel } \\
\text { Statin } \\
\text { AAS }\end{array}$ & $\begin{array}{l}\text { Late onset } \\
\text { anaphylaxis }\end{array}$ & 300 & 0 \\
\hline 4 & 78 & M & Gouty joint pathology & $\begin{array}{c}\text { HBP } \\
\text { NIDDM } \\
\text { Valvulopathy }\end{array}$ & $\begin{array}{l}\text { Fursosemide } \\
\text { Perindopril } \\
\text { Metformin } \\
\text { Sitagliptine } \\
\text { Colchicine } \\
\text { Carvedilol } \\
\text { Oxazepam }\end{array}$ & Urticaria & 300 & 0 \\
\hline 5 & 62 & M & Gouty joint pathology & $\begin{array}{l}\text { HBP } \\
\text { DVT }\end{array}$ & $\begin{array}{c}\text { Eterocoxib } \\
\text { Trimetazidine } \\
\text { Diclofenac Glucosamine }\end{array}$ & Urticaria & 300 & $\begin{array}{c}4^{\text {th }} \text { and } 6^{\text {th }} \text { days: Urticaria } \\
7^{\text {th }} \text { and } 9^{\text {th }} \text { days: Fixed erythema } \\
\text { (IM antihistamine, daily } \\
\text { antihistamine after })\end{array}$ \\
\hline 6 & 80 & $\mathrm{~F}$ & Gouty joint pathology & $\begin{array}{c}\text { HBP } \\
\text { Dyslipidemia }\end{array}$ & $\begin{array}{c}\text { AlprazolamTrimetaxidine } \\
\text { Statin } \\
\text { AAS } \\
\text { CandesartanGlucosamine }\end{array}$ & MPE & 150 & $\begin{array}{c}7^{\text {th }} \text { day: MPE } \\
\text { (IM antihistamine and IV corticoid) }\end{array}$ \\
\hline 7 & 37 & M & $\begin{array}{l}\text { Gouty joint pathology } \\
\text { and uric nephropaty }\end{array}$ & & $\begin{array}{l}\text { Losartan } \\
\text { Fenofibrate }\end{array}$ & Fixed erythema & 200 & 0 \\
\hline
\end{tabular}

Table 3: Clinical characteristics, hypersensitivity reaction to allopurinol and adverse reactions during desensitization procedure.

patients; 5 patients reached to $300 \mathrm{mg} /$ day; one to $200 \mathrm{mg}$ /day and another to $150 \mathrm{mg} /$ day.

After the protocol patients were evaluated by our clinic. One patient was lost from the consultation. The remaining six patients have improved clinically, decreasing the number of gouty attacks and had a lower urate level [mean $6.95 \mathrm{mg} / \mathrm{dL}$; range $3.7-9.8 \mathrm{md} / \mathrm{dL}$ (previous: mean 10.2; range 7.2-14.0)].

\section{Discussion}

Although the allopurinol is a well-tolerated drug, $2 \%$ of the patients develop a pruritic maculopapular rash. More severe systemic reactions, such as DRESS, SJS or TEN are scarcer, with an incidence of only $0.4 \%$. The pathophysiological mechanisms underlying these reactions are not well understood and may be immunologically mediated and/or of toxic nature. When we have a reaction to allopurinol, we can consider desensitization in patients with confirmed hypersensitivity to the molecule and there is a need for hypouricemic therapeutic.

We chose this protocol for its success rate as previous described by others $[9,27]$. We did not reach the final dose of the protocol $(300$ $\mathrm{mg}$ ) in all patients because the individual effective dose was previously defined by patient's assistant physician.

Even though this protocol was initially created for desensitization of patients with local skin reactions (fixed erythema), we observed that it was also effective in desensitization of patients with systemic reactions, thus saving time comparingwith the protocol used by Fam et al. [18] whose duration was at least a month.

However, more than half of the patients (57\%) had skin reactions during the induction phase. Two patients with fixed erythema experienced recurrence of symptoms during protocol. We had to adapt protocol bothpatients with success. None of them needed corticosteroids or other preventive therapy to achieve maintenance dose, like the patient reported by Kelso and Keating [15] who received low-dose prednisone during desensitization procedure. One patient with urticaria after the intake of allopurinol also had recurrence of symptoms during the induction phase and this patient needed premedication with anti-histamine in order to achieve maintenance dose. This was the most problematic patient of our case series and the only one who needed pre-medication.

The largest number of complications was at the $6^{\text {th }}$ and $7^{\text {th }}$ day of the protocol corresponding to a cumulative dose of $14 \mathrm{mg}$ and 51 mg of allopurinol, respectively. These reactions lead to individual management of the protocol increasing the time of the procedure. In Lopes da Silva et al. [9] series, in two of three patients who suffered a reaction, this occurred in the 8thday of the protocol.

The frequency of reactions during the protocol demonstrates the difficulty and risks of this procedure. Furthermore, the risk of adverse reaction and its severity is increased by the patient's age and by the concomitant pathology. Another risk factor in these patients is the chronic medication including beta-blockers. It is for the physician to decide whether the benefits obtained with desensitization outweigh the risks of stopping this medication.

Comparing the present study with other studies in the literature, the works of Fam et al. [18] and Lopes da Silva et al. [9], our success rate was higher ( $100 \%$ versus $66.7 \%$ and $87.5 \%$ respectively). There were no severe reactions or significant abnormal laboratory findings that led to 
Citation: Gomes R, Ribeiro F, Faria E, Loureiro C, Segorbe-Luís A (2013) Desensitization to Allopurinol in Localized and Systemic Hypersensitivity Reactions. J Allergy Ther 4: 138. doi:10.4172/2155-6121.1000138

discontinuation of treatment but the number of mild reactions during the protocol was higher (57\% versus $34.3 \%$ in Fam et al. [18]) and in $33.3 \%$ of patients in the series of Lopes da Silva et al. [9]. However in our work as well in Lopes da Silva et al. [9] there is an important limitation based on small sample compared to the Fam et al. [18] (7 and 9 versus 32).

\section{Conclusion}

The absence of uricosuric drugs in Portugal increases the need for desensitization to allopurinol in patients with hyperuricemia and HS to the drug. Our work showed that desensitization is effective despite the fact that adverse reactions during the protocol are frequent. However these reactions are minor and do not imply suspension of the procedure. Further studies are needed to investigate the mechanisms of HS reactions to allopurinol as well as those underlying the desensitization process to the drug.

\section{References}

1. Pacher P, Nivorozhkin A, Szabó C (2006) Therapeutic effects of xanthine oxidase inhibitors: renaissance half a century after the discovery of allopurinol. Pharmacol Rev 58: 87-114.

2. Cameron JS, Moro F, Simmonds HA (1993) Gout, uric acid and purine metabolism in paediatric nephrology. Pediatr Nephrol 7: 105-118.

3. Vázquez-Mellado J, Morales EM, Pacheco-Tena C, Burgos-Vargas R (2001) Relation between adverse events associated with allopurinol and renal function in patients with gout. Ann Rheum Dis 60: 981-983.

4. Vervloet D, Pradal M, Castelain M (1999) Drug allergy. Uppsala: Pharmacia \& Upjohn: 275-279.

5. Arellano F, Sacristán JA (1993) Allopurinol hypersensitivity syndrome: a review. Ann Pharmacother 27: 337-343.

6. Roujeau JC, Kelly JP, Naldi L, Rzany B, Stern RS, et al. (1995) Medication use and the risk of Stevens-Johnson syndrome or toxic epidermal necrolysis. N Engl J Med 333: 1600-1607.

7. Hung SI, Chung WH, Liou LB, Chu CC, Lin M, et al. (2005) HLA-B*5801 allele as a genetic marker for severe cutaneous adverse reactions caused by allopurinol. Proc Natl Acad Sci U S A 102: 4134-4139.

8. Stamp LK, Taylor WJ, Jones PB, Dockerty JL, Drake J, et al. (2012) Starting dose is a risk factor for allopurinol hypersensitivity syndrome: a proposed safe starting dose of allopurinol. Arthritis Rheum 64: 2529-2536.

9. Silva SL, Santos AS, Pregal AL, Pedro E, Ferreira MB, et al. (2004). Alopurinol: experiênciaemdessensibilização, Rev Port Imunoalergologia 12: 390-399.

10. Meyrier A (1976) Desensitisation in a patient with chronic renal disease and severe allergy to allopurinol. Br Med J 2: 458.

11. Teraki Y, Shiohara T (2004) Successful desensitization to fixed drug eruption: the presence of CD25+CD4+ T cells in the epidermis of fixed drug eruption lesions may be involved in the induction of desensitization. Dermatology 209: 29-32.

12. Fam AG, Lewtas J, Stein J, Paton TW (1992) Desensitization to allopurinol in patients with gout and cutaneous reactions. Am J Med 93: 299-302.

13. Audiacana M, Echechipia S, Fernández E, Urrutia I (1990) Desensitization in a case of fixed drug eruption from allopurinol. Clin Exp Allergy 20: 121.
14. Garcés M, Alonso L, Pérez R, Marcos L, Juste S, et al. (1995) Successful oral desensitization in a patient with fixed eruption from allopurinol [abstract] Allergy 50: 213

15. Kelso JM, Keating RM (1996) Successful desensitization for treatment of a fixed drug eruption to allopurinol. J Allergy Clin Immunol 97: 1171-1172.

16. Saha A, Das NK, Hazra A, Gharami RC, Chowdhury SN, et al. (2012) Cutaneous adverse drug reaction profile in a tertiary care out patient setting in Eastern India. Indian J Pharmacol 44: 792-797.

17. Walz-LeBlanc BA, Reynolds WJ, MacFadden DK (1991) Allopurinol sensitivity in a patient with chronic tophaceous gout: success of intravenous desensitization after failure of oral desensitization. Arthritis Rheum 34: 1329-1331.

18. Fam AG, Dunne SM, lazzetta J, Paton TW (2001) Efficacy and safety of desensitization to allopurinol following cutaneous reactions. Arthritis Rheum 44: 231-238.

19. Emmerson BT, Hazelton RA, Frazer IH (1988) Some adverse reactions to allopurinol may be mediated by lymphocyte reactivity to oxypurinol. Arthritis Rheum 31: 436-440.

20. Braden GL, Warzynski MJ, Golightly M, Ballow M (1994) Cell-mediated immunity in allopurinol-induced hypersensitivity. Clin Immunol Immunopatho 70: $145-151$

21. Hamanaka H, Mizutani H, Nouchi N, Shimizu Y, Shimizu M (1998) Allopurino hypersensitivity syndrome: hypersensitivity to oxypurinol but not allopurinol. Clin Exp Dermatol 23: 32-34.

22. Emmerson BT (1996) The management of gout. N Engl J Med 334: 445-451.

23. Morel D, Guez S, Merville P, Deminière C, Tamisier JM, et al. (1999) Recurrent renal failure associated with hypersensitivity to allopurinol. Nephrol Dial Transplant 14: 780-781.

24. Johansson SG, Hourihane JO, Bousquet J, Bruijnzeel-Koomen C, Dreborg S et al. (2001) A revised nomenclature for allergy. An EAACl position statement from the EAACI nomenclature task force. Allergy 56: 813-824.

25. Singer JZ, Wallace SL (1986) The allopurinol hypersensitivity syndrome. Unnecessary morbidity and mortality. Arthritis Rheum 29: 82-87.

26. Hande KR, Noone RM, Stone WJ (1984) Severe allopurinol toxicity. Description and guidelines for prevention in patients with renal insufficiency. Am J Med 76: 47-56.

27. Umpiérrez A, Cuesta-Herranz J, De Las Heras M, Lluch-Bernal M, Figueredo E, et al. (1998) Successful desensitization of a fixed drug eruption caused by allopurinol. J Allergy Clin Immunol 101: 286-287.

This article was originally published in a special issue, Drug Allergy handled

by Editor. Dr. Helieh S Oz, University of Kentucky Medical Center, USA 